\title{
Multicenter study on invasive Streptococcus pyogenes infections in children in Argentina
}

\author{
Aldo D. Cancellara M.D. ${ }^{a}$, Pablo Melonari M.D. ${ }^{b}$, María V. Firpo M.D. ${ }^{c}$, \\ Andrea Mónaco M.D. ${ }^{d}$, Gustavo C. Ezcurra M.D. ${ }^{e}$, Lía Ruiz M.D. ${ }^{f}$, Alicia M. Aletti M.D. ${ }^{g}$, \\ Gabriela Gregorio M.D. ${ }^{h}$, Alejandra Gaiano M.D. ${ }^{i}$, Alberto Aird M.D. ${ }^{j}$, \\ Luciana Bellone M.D. ${ }^{k}$, Miriam Calvari M.D. ${ }^{\prime}$, Carolina Torregrosa M.D. ${ }^{l}$, \\ Sandra Morinigo M.D. ${ }^{m}$, María L. Vozza M.D. ${ }^{n}$, Ivana Tonetto M.D. ${ }^{n}$, Luis P. Flynn M.D. ${ }^{\circ}$, \\ Nancy M. Bidone M.D. ${ }^{p}$, Carlota Russ M.D. ${ }^{9}$ and Alejandro Ellis M.D.'
}

\begin{abstract}
Introduction. Invasive Streptococcus pyogenes infections (ISpIs) cause a high morbidity and mortality, even at present; however, at a regional level there are few publications on this subject in the field of pediatrics.

Objective. To describe the prevalence, predisposing factors and clinical characteristics of children hospitalized for ISpI, and analyze risk factors associated with bacteremia and lethality. Material and methods. Retrospective, descriptive study on ISpIs in children $\leq 18$ years old hospitalized in the Pediatric Ward of 20 healthcare facilities across Argentina between 2010 and 2012. Assessed outcome measures: age, gender, early and late clinical sources of infection, prior chronic condition, predisposing factors, treatment and evolution.

Results. One hundred and forty-three patients were analyzed. The incidence of ISpI was 4.97 cases / 10000 hospital discharges. Patients' median age was 54 months old, and $11.2 \%$ had a prior chronic condition. Also, 67.1\% had predisposing factors. The most common clinical manifestations were in the skin and soft tissue in 77 patients, sepsis in 30 , bone and joint
\end{abstract}

involvement in 19, necrotizing fasciitis in 13, and toxic shock syndrome in 11. Streptococcus pyogenes was isolated in the blood cultures of $56.6 \%$. More than one clinical source of infection and no surgery were associated with bacteremia (odds ratio [OR]: 4.8, $p=0.003$ and OR: 3.1, $p=0.0012$, respectively). The average length of stay in the hospital was 13.4 days. Fatality rate was $7.6 \%$ in association with toxic shock syndrome (OR: 10, $p=0.005)$, necrotizing fasciitis (OR: 104, $p<0.0001$ ) and admission to the Pediatric Intensive Care Unit (OR: 26, $p<0.001$ ). Conclusions. Most ISpIs were observed in patients without a prior chronic condition. The most common manifestation was, frequently with bacteremia, in the skin and soft tissue. A statistically significant association was observed between bacteremia and $\geq 2$ early sources of infection and no surgery. Fatality rate, in association with streptococcal toxic shock syndrome and necrotizing fasciitis, was similar to that observed in other publications.

Key words: Streptococcus pyogenes, necrotizing fasciitis, toxic shock syndrome.

http:/ / dx.doi.org/10.5546/aap.2016.eng.199
E-mail address:

Aldo D. Cancellara, M.D.: adcancel@intramed.net

Funding:

None.

Conflict of interest:

None.

Received: 08-27-2015

Accepted: 11-23-2015 a. Hospital de Niños Pedro de Elizalde, Autonomous City of Buenos Aires.

b. Hospital Pediátrico Dr. Notti, Villa Nueva de Guaymallén, Mendoza.

c. Hospital del Niño Jesús, San Miguel de Tucumán, Tucumán.

d. Hospital de Niños Pedro de Elizalde, Autonomous City of Buenos Aires, Argentina.

e. Hospital de Niños Dr. Orlando Alassia, Santa Fe, Santa Fe.

f. Hospital de Niños de la Santísima Trinidad, Córdoba.

g. Hospital de Niños Víctor J. Vilela, Rosario.

h. Hospital A. Posadas, El Palomar, Buenos Aires.

i. Hospital Materno Infantil de San Isidro, San Isidro.

j. Hospital Infantil Municipal, Córdoba.

k. Hospital Regional Ushuaia, Ushuaia, and Hospital Regional de Río Grande, Río Grande.

1. Hospital Pediátrico del Niño Jesús, Córdoba.

11. Sanatorio Mater Dei, Autonomous City of Buenos Aires.

m. Hospital Pediátrico Dr. Avelino Castelán, Resistencia.

n. Hospital Misericordia Nuevo Siglo, Güemes Capital neighborhood, Córdoba.

ñ. Hospital Interzonal Penna, Bahía Blanca, Buenos Aires.

o. Sanatorio de Niños, Rosario, Santa Fe, and Hospital Italiano, Rosario, Santa Fe.

p. CEMIC, Autonomous City of Buenos Aires

q. Fundación Hospitalaria, Autonomous City of Buenos Aires

r. CEMIC and Sanatorio Mater Dei, Autonomous City of Buenos Aires. 


\section{INTRODUCTION}

Beta-hemolytic Streptococcus or Streptococcus pyogenes has been recognized as an important bacterial agent since the beginnings of modern microbiology and is one of the top ten leading causes of mortality due to infections. ${ }^{1}$

A wide range of clinical manifestations are the result of Streptococcus pyogenes, including pharyngitis, impetigo, scarlet fever and severe invasive infections. ${ }^{2}$ Invasive Streptococcus pyogenes infections (ISpIs) are defined as those whose pathogen is isolated in normally sterile sites (blood, cerebrospinal fluid, joint fluid, etc.), that cause bacteremia, osteomyelitis, cellulitis, meningitis, necrotizing fasciitis and streptococcal toxic shock syndrome (STSS), and have a high morbidity and mortality. ${ }^{3}$

Over the past three decades, the occurrence of ISpIs has increased worldwide. ${ }^{3-8}$ ISpI's $^{\prime}$ epidemiological features are complex. A greater aggressiveness has been associated with the emergence of more virulent strains related to M1 and M3 serotypes, capable of altering phagocyte function, and with the production of pyrogenic exotoxins, especially SpeA, which may act as superantigens. ${ }^{6,9,10}$ In adults, overall fatality rate caused by invasive infections has been observed to range from $10 \%$ to $80 \%$, in spite of an adequate management.,11 STSS accounts for more than $50 \%$ of fatality rate, while necrotizing fasciitis, for $10-20 \%$. Studies conducted in the pediatric population have evidenced that severe invasive infections are less common and less lethal, accounting for $5-10 \%$ of deaths. ${ }^{12}$

In our setting, there are very few publications available in which the clinical characteristics and the course of this type of pediatric infections are analyzed. ${ }^{13,14}$

The objective of this study is to describe the prevalence and clinical characteristics of ISpI in hospitalized children, identify its clinical signs and symptoms and risk factors, and analyze outcome measures associated with blood culture results and fatality rate.

\section{MATERIAL AND METHODS \\ Design}

Cross-sectional, descriptive, observational study conducted between January 1st, 2010 and December 31st, 2012. All patients with ISpI and hospitalized in 20 healthcare facilities located across Argentina were included. Participating facilities were those that accepted the invitation made by the National Committee on Infectious Diseases of the Argentine Society of Pediatrics.

\section{Eligibility criteria}

Patients were initially screened by reviewing the records of the Department of Microbiology of participating facilities: isolation of Streptococcus pyogenes in blood samples or puncture fluid tests (cerebrospinal, pleural, abscess or osteoarticular fluids). Medical records of identified patients were then reviewed to assess outcome measures: age, site of infection, early and late clinical sources of infection $(>72 \mathrm{~h})$, prior chronic condition, predisposing factors, lab test alterations and evolution.

\section{Inclusion criteria}

- Patients younger than 18 years old hospitalized in the Pediatric Ward (patients hospitalized in the Department of Neonatology were excluded).

- Hospitalized in any of the participating facilities, and with documented invasive Streptococcus pyogenes infection.

- Living in Argentina.

\section{Definitions}

Invasive Streptococcus pyogenes infection was considered based on the criteria established by the Working Group on Severe Streptococcal Infections, and defined as the isolation of Streptococcus pyogenes in the blood culture of a normally sterile site (cerebrospinal, synovial, peritoneal or pleural fluid) or a tissue biopsy. ${ }^{3}$

Infections were considered nosocomial if acquired more than 72 hours after the patient hospitalization.

\section{Sample size}

Assuming an invasive infection incidence of 4/10 000 hospitalizations, with a 2 in 10000 precision, it was proposed a sample including at least 38401 medical records (denominator) to assess cases with a $95 \%$ confidence level.

\section{Assessment record}

A separate record was specially designed to collect data. Assessed outcome measures included prior chronic condition, predisposing factors, clinical manifestation, microbiological characteristics, treatment and evolution (Annex).

Microbiological samples were processed and microorganisms were identified and typified using standard microbiological procedures. ${ }^{15}$ 
Necrotizing fasciitis was defined as a rapidly destructive and progressive infection of subcutaneous tissue involving the muscle fascia. ${ }^{16}$

STSS was considered based on publications. ${ }^{17}$

\section{Treatment}

The following options were considered, either in combination or monotherapy.

- Initial empiric antibiotic treatment with subsequent antibiotic cycling. Treatment was considered adequate if the empiric antibiotic had coverage against Streptococcus pyogenes, and if it was associated with clindamycin during antibiotic cycling.

- Surgery, drainage and/or debridement requirement.

- Use of intravenous gamma globulin at a recommended dose of $2 \mathrm{~g} / \mathrm{kg}$ at the time of diagnosis of STSS or necrotizing fasciitis. ${ }^{1}$

- Requirement for admission to the Pediatric Intensive Care Unit (PICU).

\section{Course}

Discharge was recorded according to one of the following criteria:

- Discharge without sequelae, discharge with sequelae, or deceased.

\section{Statistical analysis}

The incidence of ISpI was estimated based on each hospital's data.

Antibiotic susceptibility was summarized as an absolute value and a relative value of the total studied samples.

The STATA 11 software was used for data analysis. Studied cases were described using, for continuous outcome measures, mean, standard deviation, median and minimum-maximum and, for categorical outcome measures, rate and odds ratio (OR) with the corresponding $95 \%$ confidence interval. Comparisons were made based on blood culture result (positive-negative) and death (yesno) using the $\chi^{2}$ test or Fisher's test. Results were considered statistically significant if their significance level was 0.05 or lower $(p \leq 0.05)$.

\section{RESULTS}

Data from 143 patients were analyzed. Ninetytwo patients were male (64.3\%). Patients' median age was 54 months old (range: 1-168 months old); $23.8 \%$ were younger than 24 months old. Sixty-four percent of cases occurred in the spring or summer.

The overall incidence in the study period was 4.97 cases / 10000 hospital discharges $(143 / 287760)$, with a discharge rate of 3.69

TABle 1. Rate of invasive Streptococcus pyogenes infections

\begin{tabular}{|c|c|c|c|c|c|c|c|}
\hline $\mathbf{N}$ & Healthcare facility & Cases & Year 2010 & Year 2011 & Year 2012 & $\begin{array}{l}\text { Total number } \\
\text { of discharges }\end{array}$ & $\begin{array}{c}\text { Rate per } 10000 \\
\text { hospital discharges }\end{array}$ \\
\hline 1 & Hospital Notti, Mendoza & 28 & 15939 & 16616 & 16470 & 49025 & 5.7 \\
\hline 2 & Hospital del Niño Jesús, Tucumán & 23 & 9162 & 9695 & 10327 & 29184 & 7.8 \\
\hline 3 & Hospital Pedro de Elizalde, Aut. City of Bs. As. & 22 & 8386 & 7912 & 8805 & 25103 & 8.7 \\
\hline 4 & Hospital Alassia, Santa Fe & 18 & 13278 & 13087 & 12282 & 38647 & 4.6 \\
\hline 5 & Hospital de Niños de la Santísima Trinidad & 10 & 10480 & 10912 & 10592 & 31984 & 3.1 \\
\hline 6 & Hospital Vilela, Rosario, Santa Fe & 8 & 7555 & 7816 & 7779 & 23150 & 3.4 \\
\hline 7 & Hospital A. Posadas, Ramos Mejía, Bs. As. & 8 & 3695 & 3410 & 3549 & 10654 & 7.5 \\
\hline 8 & Hospital Materno Infantil de San Isidro & 6 & 1851 & 1856 & 1826 & 5533 & 10.8 \\
\hline 9 & Hospital Municipal Córdoba & 4 & 2332 & 3057 & 2448 & 7837 & 5.1 \\
\hline 10 & Hospital Regional de Ushuaia T. del Fuego & 3 & 624 & 712 & 567 & 1903 & 15.7 \\
\hline 11 & Hospital Pediátrico Niño Jesús, Córdoba & 3 & 2312 & 2410 & 2046 & 6768 & 4.43 \\
\hline 12 & Sanatorio Mater Dei, Aut. City of Bs. As. & 2 & 2650 & 2574 & 2589 & 7813 & 2.5 \\
\hline 13 & CEMIC, Aut. City of Buenos Aires & 2 & 1058 & 1169 & 1093 & 3320 & 6.0 \\
\hline 14 & Hospital A. Castelán, Resistencia, Chaco & 2 & 3205 & 4321 & 2736 & 10262 & 1.9 \\
\hline 15 & Sanatorio de Niños, Rosario, Santa Fe & 1 & 4696 & 4849 & 4742 & 14287 & 0.7 \\
\hline 16 & Hospital Italiano (Pediatric Department), Rosario, S. Fe & 0 & 659 & 494 & 489 & 1642 & 0 \\
\hline 17 & Hospital Misericordia, Córdoba & 1 & 784 & 866 & 553 & 2203 & 4.5 \\
\hline 18 & Hospital Interzonal Penna, Bahía Blanca & 1 & 1436 & 1408 & 1345 & 4189 & 2.3 \\
\hline 19 & Hospital de Río Grande, T. del Fuego & 1 & 684 & 713 & 675 & 2072 & 4.8 \\
\hline 20 & Fundación Hospitalaria, Aut. City of Bs. As. & 0 & 3903 & 3604 & 4677 & 12184 & 0 \\
\hline & Total & 143 & 94689 & 97481 & 83308 & 287760 & 4.97 \\
\hline
\end{tabular}


(35 cases), 6.15 (60 cases) and 5.76 (48 cases) per 10000 hospital discharges between 2010 and 2012, with variations among the different facilities (Table 1). Most patients (130) had acquired the infection outside the hospital setting, while $13(9 \%)$ had a nosocomial infection.

No prior chronic condition was observed in $88.8 \%$ of children $(127 / 143)$. Among the $11.2 \%$ $(16 / 143)$ of patients who had a prior chronic condition, recurrent wheezing and/or bronchial asthma was observed in 8 , heart disease in 5, diabetes in 2, and epilepsy, dysautonomia, obesity, malnutrition, rheumatic disease and hematological disease each in 1 patient. Some patients had more than one condition.

Predisposing factors were present in $67.1 \%$ of patients (93/143): chickenpox in 31, prior trauma in 31 , impetigo in 24 , surgery in 10 , eczema in 6 , burn wound in 3 . Other skin lesions not included in the above categories were more common (abrasions, lacerations, puncture wounds, etc.), which were observed in 38 patients. Some patients had more than one predisposing factor. No predisposing factor was detected in $32.9 \%$ $(47 / 143)$ of patients.

Figure 1 shows the early and late clinical manifestations. Some patients had more than one clinical source of infection. Two or more early sources of infection were observed in $26.6 \%$ $(38 / 143)$ of patients. Children with more than one early source of infection were more likely to have a positive blood culture, compared to those who had a single early source of infection (OR: $4.8, p=0.0003$ ).

Leukocytosis above $15000 / \mathrm{mm}^{3}$ was seen in $73.2 \%$ of patients, while $21.6 \%$ had more than $20000 / \mathrm{mm}^{3}$. Erythrocyte sedimentation rate $>30 \mathrm{~mm}$ in the first hour was detected in $68.0 \%$ (66/97) of studied patients. Abnormalities in liver function tests were observed in $25.5 \%$ (13/51). Lactate dehydrogenase was high in $86.7 \%(13 / 15)$ of studied patients, creatine phosphokinase was high in $77.8 \%(7 / 9)$, and creatinine, in $30.3 \%$ $(17 / 56)$ of those who had this test requested.

Streptococcus pyogenes was isolated from blood cultures in 81 patients (56.6\%); the pathogen was isolated from the skin and soft tissue in 45, from joint fluid in 10 , from cerebrospinal fluid in 7 , and from pleural fluid in 6 . The agent was isolated from more than one site in some patients.

An adequate initial empiric antibiotic treatment was administered to 142 patients (only 1 received azithromycin empirically). The antibiotic schedule was changed once culture results were available from 88 patients; in these cases, the most common schedule included betalactam antibiotics and clindamycin.

Surgical drainage was performed in 63 patients $(44.0 \%)$. Children who had no surgery were more likely to have a positive blood culture compared to those who had undergone surgery (OR: 3.1, $p=0.0012$ ) (Table 2). Intravenous gamma globulin was administered to 9 patients $(6.3 \%)$. Four patients had sequelae (2.8\%).

FIGURE 1. Early or late clinical manifestations (N: 143 patients)

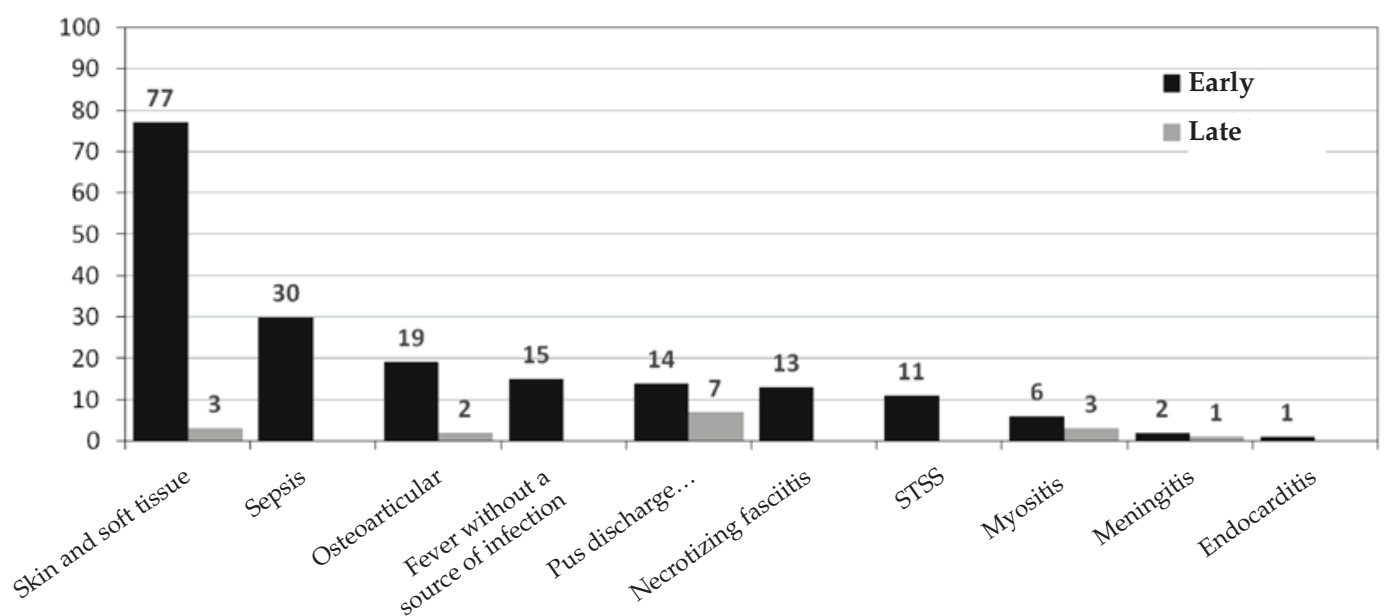

STSS: streptococcal toxic shock syndrome. 
The average hospital length of stay was 13.4 days (range: 1-80 days). Admission to the ICU was required in $20.3 \%(29 / 143)$. As per the univariate analysis, children admitted to the PICU had a much higher chance of dying than those who were not admitted to the PICU (OR: $26, p<0.0001)$ (Table 3).

The overall fatality rate was $7.69 \%$ (11 patients). Among children with STSS, death was more probable $(4 / 11)$ compared to those who did not have STSS (OR: 10, $p=0.005)$. Among children with necrotizing fasciitis death was much more probable $(5 / 11)$ compared to those who did not have it (OR: 104, $p<0.0001)$.

\section{DISCUSSION}

Over the past decades, several studies have indicated that ISpI cases have increased, both in adults and children.- ${ }^{2-5,10,18}$ In our setting, our series accounts for the largest number of cases reported in children, whose median age was 54.0 months old, similar to the median age reported by Davies et al. of 48 months old, ${ }^{12}$ and to that reported by Zachariadou et al. of 5.4 years old, but younger

TABLE 2. Outcome measures related to blood culture results. Univariate analysis

\begin{tabular}{|c|c|c|c|c|}
\hline \multicolumn{2}{|c|}{ Outcome measure } & \multicolumn{2}{|c|}{ Blood culture } & \multirow[t]{2}{*}{$p$} \\
\hline & & Negative & Positive & \\
\hline Age & $\begin{array}{l}\text { Younger than } 24 \text { months old } \\
24 \text { months or older }\end{array}$ & $\begin{array}{l}51(46.8 \%) \\
11(32.4 \%)\end{array}$ & $\begin{array}{l}58(53.2 \%) \\
23(67.7 \%)\end{array}$ & $\mathrm{p}=0.1381$ \\
\hline Prior chronic condition & $\begin{array}{c}\text { No } \\
\text { Yes (any disease) }\end{array}$ & $\begin{array}{l}55(43.3 \%) \\
7(43.8 \%)\end{array}$ & $\begin{array}{l}72(56.7 \%) \\
9(56.3 \%)\end{array}$ & $\mathrm{p}=0.9731$ \\
\hline Early source of infection & $\begin{array}{c}1 \\
2 \text { or more sources of infection }\end{array}$ & $\begin{array}{l}55(52.4 \%) \\
7(18.4 \%)\end{array}$ & $\begin{array}{l}50(47.6 \%) \\
31(81.6 \%)\end{array}$ & $\mathrm{p}=0.0003$ \\
\hline Toxic shock syndrome & $\begin{array}{l}\text { No } \\
\text { Yes }\end{array}$ & $\begin{array}{l}60(45.5 \%) \\
2(18.2 \%)\end{array}$ & $\begin{array}{l}72(54.6 \%) \\
9(81.8 \%)\end{array}$ & $\mathrm{p}=0.1141$ \\
\hline Necrotizing fasciitis & $\begin{array}{l}\text { No } \\
\text { Yes }\end{array}$ & $\begin{array}{l}58(44.6 \%) \\
4(30.8 \%)\end{array}$ & $\begin{array}{l}72(55.4 \%) \\
9(69.2 \%)\end{array}$ & $\mathrm{p}=0.3925$ \\
\hline Leukocytes $>20000 / \mathrm{mm}^{3}$ & $\begin{array}{l}\text { No } \\
\text { Yes }\end{array}$ & $\begin{array}{l}42(39.6 \%) \\
17(53.1 \%)\end{array}$ & $\begin{array}{l}64(60.4 \%) \\
15(46.9 \%)\end{array}$ & $\mathrm{p}=0.1760$ \\
\hline Surgery & $\begin{array}{l}\text { No } \\
\text { Yes }\end{array}$ & $\begin{array}{l}25(31.7 \%) \\
37(58.7 \%)\end{array}$ & $\begin{array}{l}54(68.4 \%) \\
26(41.3 \%)\end{array}$ & $\mathrm{p}=0.0012$ \\
\hline Intensive Care Unit & $\begin{array}{l}\text { No } \\
\text { Yes }\end{array}$ & $\begin{array}{l}54(47.8 \%) \\
8(27.6 \%)\end{array}$ & $\begin{array}{l}59(52.2 \%) \\
21(72.4 \%)\end{array}$ & $\mathrm{p}=0.0504$ \\
\hline Death & $\begin{array}{l}\text { No } \\
\text { Yes }\end{array}$ & $\begin{array}{l}59(45 \%) \\
3(27.3 \%)\end{array}$ & $\begin{array}{l}72(55 \%) \\
8(72.7 \%)\end{array}$ & $\mathrm{p}=0.3483$ \\
\hline
\end{tabular}

TABLE 3. Outcome measures associated with lethality. Univariate analysis.

\begin{tabular}{|c|c|c|c|c|}
\hline \multicolumn{2}{|c|}{ Signs, symptoms and risk factors } & \multicolumn{2}{|c|}{ Death } & \multirow[t]{2}{*}{$p$} \\
\hline & & Negative & Positive & \\
\hline$\overline{\text { Age }}$ & $\begin{array}{l}\text { Younger than } 24 \text { months old } \\
24 \text { months or older }\end{array}$ & $\begin{array}{l}100(92.6 \%) \\
31(91.2 \%)\end{array}$ & $\begin{array}{l}8(7.4 \%) \\
3(8.8 \%)\end{array}$ & $\mathrm{p}=0.7247$ \\
\hline Prior chronic condition & $\begin{array}{c}\text { No } \\
\text { Yes (any disease) }\end{array}$ & $\begin{array}{l}115(91.3 \%) \\
16(100 \%)\end{array}$ & $\begin{array}{l}11(8.7 \%) \\
0(0 \%)\end{array}$ & $\mathrm{p}=0.6133$ \\
\hline Early source of infection & $\begin{array}{c}1 \\
2 \text { or more sources of infection }\end{array}$ & $\begin{array}{l}99(94.3 \%) \\
32(86.5 \%)\end{array}$ & $\begin{array}{l}6(5.7 \%) \\
5(13.5 \%)\end{array}$ & $p=0.1546$ \\
\hline Toxic shock syndrome & $\begin{array}{l}\text { No } \\
\text { Yes }\end{array}$ & $\begin{array}{l}124(94.7 \%) \\
7(63.6 \%)\end{array}$ & $\begin{array}{l}7(5.3 \%) \\
4(36.4 \%)\end{array}$ & $\mathrm{p}=0.0050$ \\
\hline Necrotizing fasciitis & $\begin{array}{l}\text { No } \\
\text { Yes }\end{array}$ & $\begin{array}{l}124(95.4 \%) \\
7(58.3 \%)\end{array}$ & $\begin{array}{l}6(4.6 \%) \\
5(41.7 \%)\end{array}$ & $\mathrm{p}<0.0001$ \\
\hline Leukocytes >20 000/ $\mathrm{mm}^{3}$ & $\begin{array}{l}\text { No } \\
\text { Yes }\end{array}$ & $\begin{array}{l}98(92.5 \%) \\
28(90.3 \%)\end{array}$ & $\begin{array}{l}8(7.6 \%) \\
3(9.7 \%)\end{array}$ & $\mathrm{p}=0.7116$ \\
\hline Surgery & $\begin{array}{l}\text { No } \\
\text { Yes }\end{array}$ & $\begin{array}{l}74(94.9 \%) \\
56(88.9 \%)\end{array}$ & $\begin{array}{l}4(5.1 \%) \\
7(11.1 \%)\end{array}$ & $\mathrm{p}=0.2811$ \\
\hline Pediatric Intensive Care Unit & $\begin{array}{l}\text { No } \\
\text { Yes }\end{array}$ & $\begin{array}{l}111(98.2 \%) \\
19(67.9 \%)\end{array}$ & $\begin{array}{l}2(1.8 \%) \\
9(32.1 \%)\end{array}$ & $\mathrm{p}<0.0001$ \\
\hline
\end{tabular}


than the mean age referred by Burnett of 7.8 years old. ${ }^{20}$

Although in our study the hospitalization rate was greater in 2012 than at the study initiation, the limited period allows to show an actual increasing trend in invasive infections, as pointed out by other publications. $5,7,8,21$

A history of chronic conditions was detected in $11.2 \%$ of children, similar to what was reported by Stockmann in a review of 1514 ISpI cases in Utah, where $11 \%$ of children and $51 \%$ of adults had a history of comorbidities $(p<0.001) .{ }^{7}$ In our series, the most common chronic conditions were recurrent wheezing and/or asthma, followed by heart disease, which was the prevailing condition in Stockmann's study. ${ }^{7}$ A review of the literature regarding adult patients evidences that a prior disease is more common in this population than among pediatric patients. ${ }^{6,16,22}$

Predisposing factors were observed in $67.1 \%$ of our patients. Chickenpox as a predisposing factor was well described by Laupland et al. ${ }^{23}$ In our study, chickenpox was detected in $21.6 \%$ of patients, similar to what was reported by Zachariadou et al., ${ }^{19}$ and higher than in other recent studies conducted in other countries of the same region where chickenpox immunization is part of the national immunization schedule. ${ }^{18}$ According to the predisposing factors observed in our series, skin was the prevailing source of infection. ${ }^{24}$

Skin and soft tissue infection was the most common early source of disease, similar to other publications. ${ }^{7,14,22,24-26}$ The rate of necrotizing fasciitis and STSS is lower than what has been published regarding adults ${ }^{10,12}$ and similar to or lower than what was reported in other pediatric series. ${ }^{9,14,19,25-29}$

Bacteremia was present in $56.6 \%$ of our patients, which is higher than what was referred in our setting by Paganini et al. (39\%), ${ }^{14}$ similar to the reports of Cancellara et al. $(64 \%),{ }^{26}$ and somewhat lower than the $72 \%^{28}$ and $74 \%{ }^{19}$ reported in the international literature.

In our review, leukocytosis above $20000 / \mathrm{mm}^{3}$ was not associated with a higher rate of bacteremia and fatality. Given the retrospective design of this study, there might be a bias in requested lab tests, which may have been ordered in those patients who had a more severe condition.

Purulent material was drained in $44.4 \%$ of patients as part of treatment, which is related to the prevailing skin and soft tissue sources of infection. Not having undergone a surgery was associated with a higher rate of bacteremia.

Although Shah et al. ${ }^{30}$ did not find a statistically significant difference in mortality among patients with STSS who received intravenous gamma globulin and placebo, there is consensus regarding the use of intravenous gamma globulin in the more severe forms of ISpI. ${ }^{31}$ Given the retrospective nature of our study, not all facilities had recorded the gamma globulin schedule used and, although we believe use was scarce, the rate of overall fatality rate was similar to that published by other authors.

All, except one patient, received an adequate initial antibiotic treatment, which was then adapted to the recommended schedule with beta-lactams and clindamycin once culture results were available. ${ }^{31-34}$

Only a small number of our patients (9\%) acquired the infection in the hospital setting, which was in general associated with prior surgeries.

The fatality rate in our study was $7.69 \%$, similar to that reported in other publications in the pediatric field..$^{14,28,35}$ The fatality rate associated with STSS and necrotizing fasciitis was 36\% (4/11) and $38 \%(5 / 13)$, respectively. This underscores the highly-specific fatality rate caused by these two conditions, similar to what has been observed by Johansson, who described a $67 \%$ STSS fatality rate, compared to $4.9 \%$ among those who did not have STSS. ${ }^{24}$

One of the limitations of this study is that the sample size was not enough to perform a multivariate analysis; in addition, and for the same reason, other significant associations may have gone undetected.

Another limitation is that, given the study's retrospective nature, it was not possible to establish whether the fatality rate observed in our study was related to other Streptococcus pyogenes virulence factors (based on antibiotic susceptibility, serotypes or emm genotypes, as mentioned in other publications). ${ }^{4,6,11,13,35}$ Also, in this study the time elapsed between the onset of symptoms and the introduction of treatment with adequate antibiotics was not assessed.

ISpI is an ongoing health problem with a high rate of morbidity and mortality. It is important to suspect ISpI during an early diagnosis so as to start an adequate management.

\section{CONCLUSIONS}

Most ISpIs were observed in patients without a prior chronic condition. The most common 
manifestation was, frequently with bacteremia, in the skin and soft tissue. A statistically significant association was observed between bacteremia and more than two early sources of infection and no surgery. Fatality rate, in association with STSS and necrotizing fasciitis, was similar to that observed in other publications.

\section{Acknowledgments}

We would like to thank Laura Gutiérrez, B.S. in Statistics, Adriana Isola, Systems Analyst, the Work Group, and the Department of Bacteriology.

\section{REFERENCES}

1. Waddington CS, Snelling TL, Carapetis JR. Management of invasive group A streptococcal infections. J Infect 2014;69 (Suppl 1):s63-9.

2. Ralph AP, Carapetis JR. Group A streptococcal diseases and their global burden. Curr Top Microbiol Immunol 2013; $368: 1-27$.

3. Hoge CW, Schwartz B, Talkington DF, Breiman RF, etal. The changing epidemiology of invasive group A streptococcal infections and the emergence of streptococcal toxic shocklike syndrome. JAMA 1993;269(3):384-9.

4. Ibeke T, Tominaga K, Shima T, Okuno R, et al. Increased prevalence of group A Streptococcus isolates in streptococcal toxic shock syndrome cases in Japan from 2010 to 2012. Epidemiol Infect 2015;143(4):864-72.

5. Moses AE, Ziv A, Harari M, Rahav G, et al. Increased incidence and severity of Streptococcus pyogenes bacteremia in young children. Pediatr Infect Dis J 1995;14(9):767-70.

6. O'Loughlin RE, Roberson A, Cieslak PR, Lynfield R, et al. The epidemiology of invasive group A streptococcal infection and potential vaccine implications: United States, 2000-2004. Clin Infect Dis 2007;45(7):853-62.

7. Stockmann C, Ampofo K, Hersh AL, Blaschke AJ, et al. Evolving epidemiologic characteristics of invasive group A streptococcal disease in Utah, 2002-2010. Clin Infect Dis 2012;55(4):479-87.

8. Svensson N, Oberg S, Henriques B, Holm S, et al. Invasive group A streptococcal infections in Sweden in 1994 and 1995: epidemiology and clinical spectrum. Scand J Infect Dis 2000;32(6):609-14.

9. Filleron A,Jeziorski E,Michon AL, Rodiére M, etal. Current insights in invasive group A streptococcal infections in pediatrics. Eur J Pediatr 2012;171(11):1589-98.

10. Zurawski CA, Bardsley M, Beall B, ElliottJA, et al. Invasive group A streptococcal disease in metropolitan Atlanta: a population based assessment. Clin Infect Dis 1998; 27(1): 150-7.

11. Lamagni TL, Neal S, Keshishian C, Powell D, et al. Predictors of death after severe Streptococcus pyogenes infection. Emerg Infect Dis 2009;15(8):1304-7.

12. Davies HD, Matlow A, Scriver SR, Schielevert P, et al. Apparent lower rates of streptococcal toxic shock syndrome and lower mortality in children with invasive group A streptococcal infections compared with adults. Pediatr Infect Dis J 1994;13(1):49-56.

13. Lopardo HA, Vidal P, Sparo M, Jeric P, et al. Six-month multicenter study on invasive infections due to Streptococcus pyogenes and Streptococcus dysgalactiae subsp. equisimilis in Argentina. J Clin Microbiol 2005;43(2):802-7.

14. Paganini H, Luppino V, Hernández C, Seú S, et al. Infecciones invasivas por Streptococcus $\beta$-hemolítico del
Grupo A. Arch Argent Pediatr 2001;99(1):9-13.

15. Versalovic J, Carroll KC, Funke G, Jorgensen JH, et al. Manual of Clinical Microbiology. 10th ed. Washington DC: American Society for Microbiology; 2011.

16. Kaul R, Mc Geer A, Low DE, Green K, et al. Population based surveillance for group A streptococcal necrotizing fasciitis: clinical features, prognostic indicators, and microbiologic analysis of seventy-seven cases. Ontario Group A Streptococcal Study. Am J Med 1997;103(1):18-24.

17. Working Group on Severe Streptococcal Infections. Defining the Group A streptococcal toxic shock syndrome. Rationale and consensus definition. JAMA 1993;269(3):390-1.

18. Vomero A, García G, Pandolfo S, Zunino C, et al. Enfermedades invasoras por Streptococcus pyogenes 20052013. Hospital Pediátrico del Centro Hospitalario Pereira Rossell, Uruguay. Rev Chilena Infectol 2014;31(6):729-34.

19. Zachariadou L, Stathi A, Tassios PT, Pangalis A, et al. Differences in the epidemiology between paediatric and adult invasive Streptococcus pyogenes infections. Epidemiol Infect 2014;142(3):512-9.

20. Burnett AM, DomachowskeJB. Therapeutic considerations for children with invasive group A streptococcal infections: a case series report and review of the literature. Clin Pediatr (Phila) 2007;46(6):550-5.

21. Vallalta Morales M, Soriano Navarro CJ, Salavert Lletit M, Montero Alonso M, et al. Group A streptococcal bacteremia: outcome and prognosis factors. Rev Esp Quimioter 2006;19(4):367-75.

22. Megged O, Yinnon AM, Raveh D, Rudensky B, et al. Group A streptococcus bacteraemia: comparison of adults and children in a single medical centre. Clin Microbiol Infect 2006;12(2):156-62.

23. Laupland KB, Davies HD, Low DE, Schwartz B, et al. Invasive group A streptococcal disease in children and association with varicella-zoster virus infection. Ontario Group A Streptococcal Study Group. Pediatrics 2000;105(5):E60.

24. Johansson L, Thulin P, Low DE, Norrby-Teglund A. Getting under the skin: the immunophatogenesis of streptococcus pyogenes deep tissue infections. Clin Infect Dis 2010; 51(1): 58-65.

25. Alarcón C, Ordenes MC, Denegri M, Zúñiga J. Infecciones invasoras porStreptococcus -hemolítico Grupo A. Rev Chil Pediatr 2006;77(5):487-91.

26. Cancellara A, DondoglioP, Baich Fernández A. Infecciones invasivas por Streptococcus pyogenes en pediatría [abstract]. En X Congreso Sociedad Argentina de Infectología; 2010; Mar del Plata.

27. Minodier P, Bidet P, Rallu F, Tapiero B, et al. Clinical and microbiologic characteristics of group A streptococcal necrotizing fasciitis in children. Pediatr Infect Dis J 2009;28(6):541-3.

28. Mulla ZD. Clinical and epidemiologic features of invasive group A streptococcal infections in children. Pediatr Int 2007;49(3):355-8.

29. Huang YC, Huang YC, Chiu CH, Chang LY, et al. Characteristics of group A streptococcal bacteremia with comparison between children and adults. J Microbiol Immunol Infect 2001;34(3):195-200.

30. Shah SS, Hall M, Srivastava R, Subramony A, et al. Intravenous Immunoglobulin in children with streptococcal toxic shock syndrome. Clin Infect Dis 2009;49(9):1369-76.

31. American Academy of Pediatrics. Group A Streptococcal infections. In: Kimberlin DW, ed. Red Book: 2015 Report of the Committee on Infectious Diseases. 30th ed. Elk Grove Village, IL: American Academy of Pediatrics; 2015. Pages 732-44. 
32. American Academy of Pediatrics. Committee on Infectious Diseases. Severe invasive Group A streptococcal infections: a subject review. Pediatrics 1998;101(1 Pt 1):136-40.

33. Sociedad Argentina de Pediatría. Comité Nacional de Infectología. Streptococcus pyogenes. In Libro Azul de Infectología Pediátrica. 4.ta ed. Buenos Aires: SAP; 2012. Pages 663-7.
34. Zimbelman J, Palmer A, Todd J. Improved outcome of clindamycin compared with beta-lactam antibiotic treatment for invasive Streptococcus pyogenes infection. Pediatr Infect Dis J 1999;18(12):1096-100.

35. Lithgow A, Duke T, Steer A, Smeesters PR. Severe group A streptococcal infections in a paediatric intensive care unit. J Paediatric Child Health 2014;50(9):687-92. 


\section{ANNEX}

\section{DATA COLLECTION RECORD}

MULTICENTER STUDY ON INVASIVE STREPTOCOCCUS PYOGENES INFECTIONS IN CHILDREN IN ARGENTINA

Healthcare facility:

Date of birth:

Address (city):

Admission date:

Total hospital length of stay:

\begin{tabular}{|c|c|c|}
\hline \multicolumn{1}{|c|}{ PRIOR CHRONIC CONDITION } & YES & NO \\
\hline DIABETES & & \\
\hline CHRONIC HEART DISEASE & & \\
\hline CHRONIC LUNG DISEASE & & \\
\hline IMMUNODEFICIENCY & & \\
\hline$\cdot$ HIVinfection & & \\
\hline$\cdot$ Hematooncological disease & & \\
\hline$\cdot$ Rheum atic disease & & \\
\hline$\cdot$ Use of immunosuppressive therapy & & \\
\hline ALCOHOLISM & & \\
\hline NDRUG ADDICTION & & \\
\hline
\end{tabular}

Initials:

Age (months):

Gender:

Discharge date:

Site of acquisition:

\begin{tabular}{|l|l|l|}
\hline \multicolumn{1}{|c|}{ PREDISPOSING FACTORS } & YES & NO \\
\hline TRAUMA & & \\
\hline SURGERY & & \\
\hline OTHER SKIN LESIONS & & \\
\hline ECZEMA & & \\
\hline BURN WOUNDS & & \\
\hline IMPETIGO & & \\
\hline CHICKENPOX & & \\
\hline
\end{tabular}

\begin{tabular}{|l|l|l|}
\hline \multicolumn{1}{|c|}{ CLINICAL PRESENTATIONS } & INITIAL & $\begin{array}{c}\text { LATE } \\
(>72 \mathrm{~h})\end{array}$ \\
\hline SKIN AND SOFT TISSUE & & \\
\hline MYOSITIS & & \\
\hline OSTE OARTICULAR & & \\
\hline PLEUROPULMONARY & & \\
\hline FEVER WITHOUT A SOURCE OF INFECTION & & \\
\hline SEPSIS & & \\
\hline NECROTIZING FASCIITIS & & \\
\hline STREPTOCOCCAL TOXIC SHOCK SYNDROME & & \\
\hline OTHERS & & \\
\hline
\end{tabular}


ISOLATION SITE (INDICATE ALL)

\begin{tabular}{|c|c|c|c|c|c|}
\hline BLOOD & CSF & JOINT FLUID & $\begin{array}{c}\text { PLEURAL } \\
\text { FLUID }\end{array}$ & $\begin{array}{c}\text { SKIN AND SOFT } \\
\text { TISSUE }\end{array}$ & $\begin{array}{c}\text { OTHERS } \\
\text { (SPECIFY) }\end{array}$ \\
\hline & & & & & \\
\hline
\end{tabular}

CSF: cerebrospinal fluid.

\section{ANTIBIOTIC SUSCEPTIBILITY}

\begin{tabular}{|l|l|}
\hline \multicolumn{1}{|c|}{ LAB TESTS } & RESUIT \\
\hline - BLOOD COUNT & \\
\hline - ERYTHROCYTE SEDIMENTATION RATE & \\
\hline - QUANTITATIVE CRP & \\
\hline - LIVER FUNCTION TESTS & \\
\hline - LDH & \\
\hline - CPK & \\
\hline - BLOOD UREA & \\
\hline - CREATININE & \\
\hline & \\
\hline
\end{tabular}

CRP: C-reactive protein; LDH: lactate dehydrogenase; CPK: creatine phosphokinase.

\begin{tabular}{|l|l|l|}
\hline \multicolumn{1}{|c|}{ TREATMENT } & $\begin{array}{c}\text { DURATION } \\
\text { (days) }\end{array}$ & $\begin{array}{c}\text { ADMINISTRATION } \\
\text { ROUTE }\end{array}$ \\
\hline INITIAL EMPIRIC TREATMENT: & & \\
\hline ANTIBIOTICS CYCLING: & & \\
\hline
\end{tabular}

\begin{tabular}{|l|c|c|}
\hline SURGERY (indicate) & YES & NO \\
\hline & & \\
\hline
\end{tabular}

\begin{tabular}{|l|c|c|}
\hline GAMMA GLOBULIN & YES & NO \\
\hline
\end{tabular}

\begin{tabular}{|l|c|c|}
\hline ADMISSION TO ICU & YES & NO \\
\hline & & \\
\hline
\end{tabular}

ICU: intensive care unit.

\begin{tabular}{|c|c|c|}
\hline \multicolumn{3}{|c|}{ DISCHARGE } \\
\hline $\begin{array}{c}\text { Without } \\
\text { sequelae }\end{array}$ & $\begin{array}{c}\text { With } \\
\text { sequelae }\end{array}$ & Deceased \\
\hline
\end{tabular}

